\title{
MICROBIAL MATS IN THE INLAND SALINE LAKES OF SPAIN
}

\author{
M. C. Guerrero' and R. de Wit ${ }^{2}$ \\ 1. Lab. Limnología. Depto. de Ecología. Universidad Autónoma de Madrid. 28049 Madrid. Spain. \\ 2. Dept. of Environmental Chemistry. Centro de Investigación y Desarrollo (C.S.I.C.). Jordi Girona, 18-26; 08034 Barcelona. \\ Spain.
}

Keywords: Spain, Endorheic saline lakes, Alkaline lakes, Microbial mats, Annual cycles, Microcoleus chthonoplastes.

\begin{abstract}
The Iberian Peninsula possesses a particular richness of inland saline lakes which mainly occur in three endorheic regions in Aragón, La Mancha and Andalucía. The distribution of benthic microbial mat communities in these lakes is described and related to the ionic composition, salinity fluctuations, inundation period and sediment features. It was found that the cyanobacterium Microcoleus chthonoplastes is the most widespread species that occurs under a whole range of environmental conditions among which e.g., high $\mathrm{Na}^{+}$, high $\mathrm{Mg}^{2}+$ and high $\mathrm{pH}$. The species composition and the annual cycle is described in more detail for four different mat types. Finally, the scientific and naturalistic values of the microbial mats in inland lakes are discussed. We propose that the presence of interesting microbial communities should be used as an important element for wetland conservation policies.
\end{abstract}

\section{INTRODUCTION}

Microbial mats are benthic communities dominated by microorganisms which form cohesive layers at the sediment surface. Commonly, these layers can be peeled off the sediment and, apparently, the ecosystem owes its name to this feature. Phototrophic oxygen-producing microorganisms which include cyanobacteria and algae, are primary producers in most microbial mats. In addition, a large chemoorganotrophic bacterial flora thrives on the excretion products and dead material from the phototrophs. Due to the high respiration activities, anoxic conditions are established only a few tenths of mm below the zone of oxygen photosynthesis (REVSBECH et al., 1983). In the anoxic zone, sulphatereducing bacteria produce sulphide. Hence, sulphide-oxidizing bacteria comprising phototrophic and chemotrophic sulphur bacteria often form clearly visible laminas at the oxygen-sulphide interface just below the oxygenic phototrophs.

Dense layers of benthic oxygenic phototrophs only develop if animal grazing is repressed and competition from macrophytes is virtually absent. Therefore, microbial mats only develop in extreme environments and are commonly found at high temperatures along the outflow of thermal wells, temporarily flooded plains in marine environment and hypersaline environments. In this volume, microbial mats on coastal plains are described by ESTEVE et al. (1992) and those found in coastal salinas are described by DE WIT \& GRIMALT (1992).

Continental saline and hypersaline lakes occur worldwide in semiarid climates (WILLIAMS, 1986) and are also a characteristic feature of the Iberian peninsula (MONTES \& MARTINO, 1987). An extensive literature study on microbial mats in inland saline lakes has been published by BAULD (1981). Different mats have been found in the lakes of the Great Rift Valley (Africa), the deserts of America and Australia. More information on mats in Australian lakes is provided by BAULD (1986). However, studies of microbial mats in inland salt lakes are restricted and mainly focused on descriptions of cyanobacterial and algal species. Thus, most current research on microbial mats that addresses more fundamental ecological and physiological questions, has been performed in thermal and coastal environments only. Nevertheless, Spanish inland salt lakes encompass a much wider variety of ionic composition types (MONTES \& MARTINO, 1987), seasonal fluctuations and sediment features than the thalassic water bodies. We will focus on the fact that these diverse inland environments represent an 
ideal research object to study which environmental factors allow the formation of microbial mats.

\section{ABUNDANCE AND VARIETY OF INLAND SALT LAKES IN SPAIN}

The presence of inland saline lakes is one of the most original limnological elements of the Iberian Peninsula. These waterbodies are associated with endorheic phenomena in semiarid climates and, in Western Europe, are thus confined to Spain. These lakes occur in groups known as limnological districts or endorheic centers. Their distribution is shown in figure 1. In this figure we did not include the subsaline lakes (up to $10 \mathrm{~g} / \mathrm{L}$ salinity) as for example found in the Duero basins. As a rule, no microbial mats were found in these lakes. However, an exception was made for the highly alkaline ( $\mathrm{pH} 9.5$ to 11 ) soda lakes found close to Coca (Segovia), since some interesting mats have been found in them.

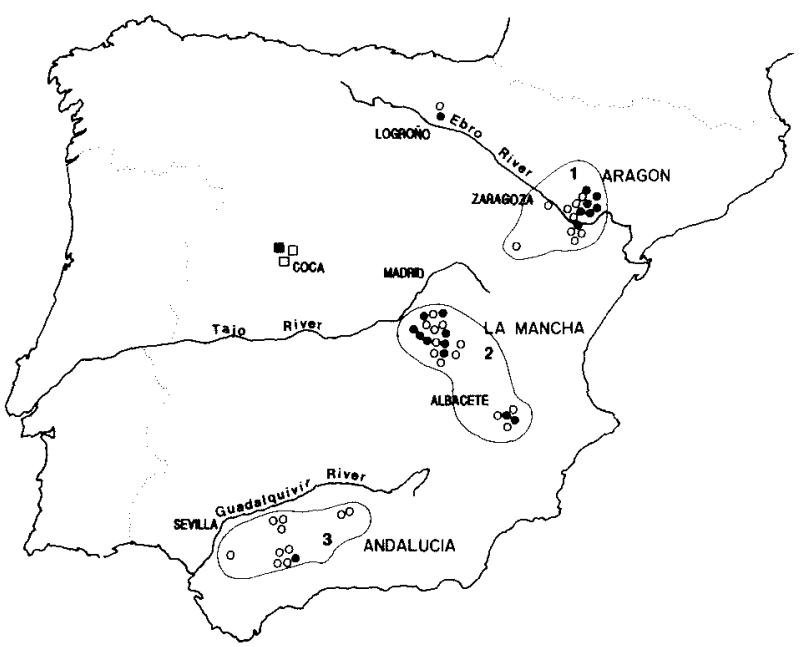

Figure 1. Map of the Iberian Peninsula indicating the occurrence of microbial mats in inland saline or alkaline lakes (closed circles $=$ saline lake with conspicuous microbial mats; open circles $=$ saline lake in which no microbial mats have been found so far; closed square $=$ subsaline soda lake $(\mathrm{pH}>9.5)$ with microbial mats: open squares=subsaline soda lakes without conspicuous microbial mats)

The ionic composition of the inland saline lakes has been studied previously by COMIN \& ALONSO (1988) and MONTES \& MARTINO (1987). In summary, the Spanish inland lakes encompass a wide spectrum of ionic types: in the Andalucian lakes sodium predominates with either chloride of sulphate as the dominant anion; the lakes in $\mathrm{La}$
Mancha mainly contain magnesium sulphate; and the lakes in Aragón encompass a whole range from sodium chloride to magnesium sulphate. The unique permanent lake "La Salada de Chiprana" belongs to the magnesium sulfate type (GUERRERO et al., 1991). Strikingly, the highly alkaline lakes close to Coca (Segovia) are of the sodium carbonate type and, thus, are typical examples of soda lakes.

The Spanish continental salt lakes encompass a broad variety of different physico-chemical conditions, seasonal fluctuations and sediment features. Lake Chiprana (Sp. "Salada de Chiprana") (Chiprana, Zaragoza) is the only deep permanent hypersaline lake found in Spain. This lake is stratified during almost the entire year, has a maximum depth of $5.6 \mathrm{~m}$ and a total surface of $31 \mathrm{ha}$; the general physicochemical and geomorphological features have been described by GUERRERO et al. (1991). In contrast, all other Spanish saline lakes are shallow and temporal water basins which contain water during 3 to 10 months of the year. During the inundation periods, the water level and concomitantly the salinity of these shallow lakes is subjected to extreme temporal fluctuations.

Figure 2 shows the fluctuations of the salinity during the studied periods as found in the temporal shallow lake "La Dehesilla" (Cuenca, Manchego endorheic district) (period 1988-1989) and the permanent saline lake Chiprana (1989). In "La Dehesilla" the salinity fluctuations amounted to a factor five (20 to $100 \mathrm{~g} / \mathrm{L}$ ). In contrast, in lake Chiprana, the salinity was remarkably constant in the anoxic bottom layer, while the salinity fluctuations of the oxic top layer were aproximately two and half fold (30 to $73 \mathrm{~g} / \mathrm{L}$ ). During the year 1989, Lake Chiprana was only once overturned during the stormy days of October: So far, it is not known if the overturn was an uncommon event or is repeated every year. Hence, this lake can not be classified yet as mono- of meromictic.

\section{AN OVERVIEW OF THE MICROBIAL MATS FOUND IN THE SPANISH INLAND SALT LAKES}

One of the most interesting examples of consistent microbial mats in Spanish inland lakes is found in the unique permanent hypersaline Lake Chiprana. The sediments of gentle slope from about $1.5 \mathrm{~m}$ water depth up to the shore, are covered with microbial mats alternated with prairies of the macrophyte Ruppia maritima var. maritima. Both communities are clearly segregated in space. Very thick $(4-9 \mathrm{~mm})$ and cohesive mats 


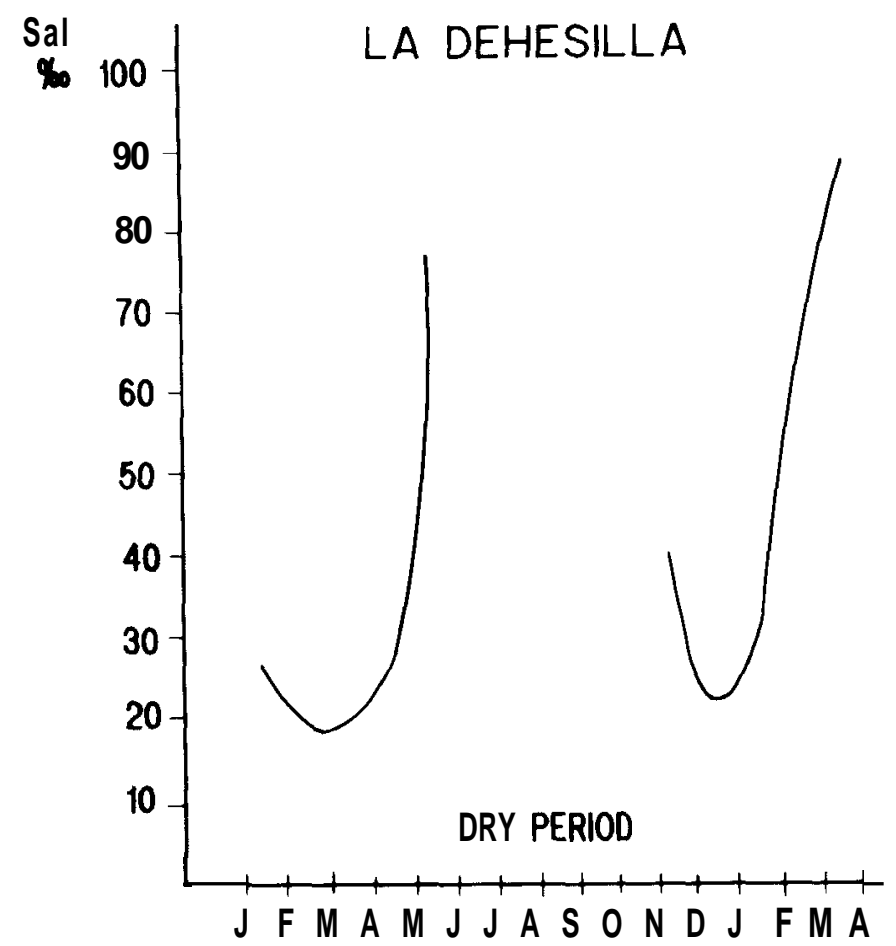

SALADA DE CHIPRANA

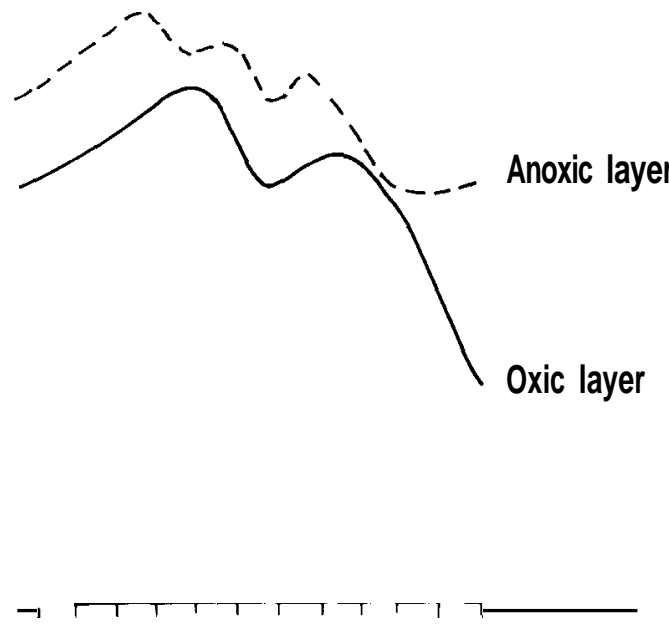

J F M A M J J A S O N D

Figure 2. Seasonal variation of the salinities $1 n$ two inland lakes: The saline to hypersaline temporary shallou lake "La Dehesilla" (La Mancha) (hydrological cycle 1988-89); The hypersaline permanent lake "La Salada de Chiprana" (Bajo Aragón) (hydrological cycle 1989).

are found on the sediments permanently covered by water. In contrast, the mats in the littoral zone which are only temporarily submerged, are thin and fragile.

The major mat-forming organism in lake Chiprana is the filamentous and bundle-forming cyanobacterium Microcoleus chthonoplastes. Figure 3 shows a schematical drawing of the stratification of microbial populations during summer in submerged mats. Along a vertical thickness of 4 to $9 \mathrm{~mm}$, several layers can be distinguished. The surface layer is composed primarily by diatoms and unicellular cyanobacteria belonging to the genera Gloeocapsa, and Synechococcus. Below, several green layers can be distinguished, which consist mainly of Microcoleus chthonoplastes together with other filamentous and unicellular cyanobacteria. These layers are rich in trapped sediment particles. The filamentous species include: Oscillatoria (O. cf. nigroviridis Geitler), Spirulina, Pseudoanabaena, Phormidium (Geitler). Unicellular cyanobacteria are represented as cominon members by gen. Gloeocapsa and Synechococcus. Other morphologically conspicuous bacteria found in the mat include Beggiatoa sp.. Spirillum sp., and filamentous bacteria which resemble the green phototrophic bacterium $C h l o$ - roflexus. Below the mat, a black sulphide-containing sediment is found. as a result of the activity of sulphate-reducing bacteria.

The most conspicuous changes found in the permanently submerged mats of Lake Chiprana during a year cycle are summarized in figure 4. Characteristically, during most time of the year, the top of the mat presents picks formations, known as "pinnacle mat" which have also been described for mats in the thermal environment (BROCK, 1978). Pinnacle formation is originated by the grouping and vertical to oblique orientation of $M$. chthonoplastes bundles. The quantitative importance of the other cyanobacteria except $\mathrm{M}$. chthonoplastes differs along the annual cycle. In summer time, underneath the cyanobacterial layer, a thin red coloured layer was found. This layer. which never cxceeded $1 \mathrm{~mm}$ thickness, consists of phototrophic purple sulfur bacteria. The representatives of the genera Chromatium and Thiospirillum predominate. In winter time, these phototrophic organisms can be found dispersed in between the cyanobacterial layer. Conceivably, these mat scasonal variations may be related to seasonal fluctuations of several physico-chemical factors. 


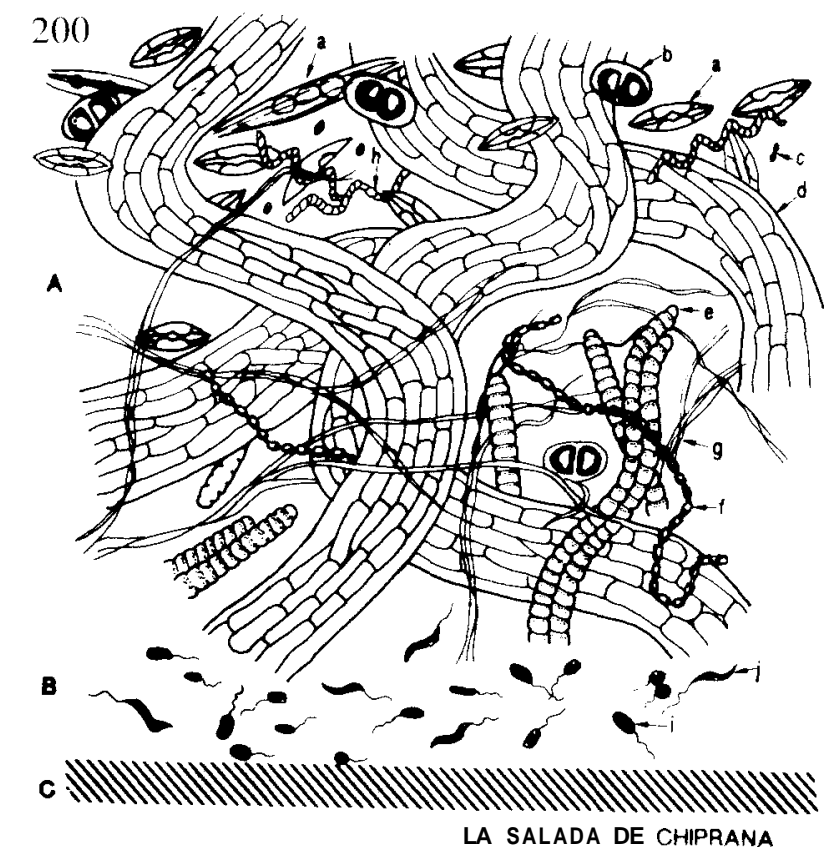

A

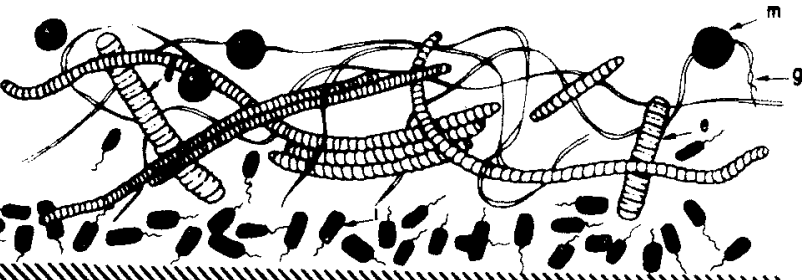

c

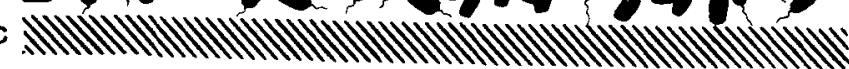

LONGAR

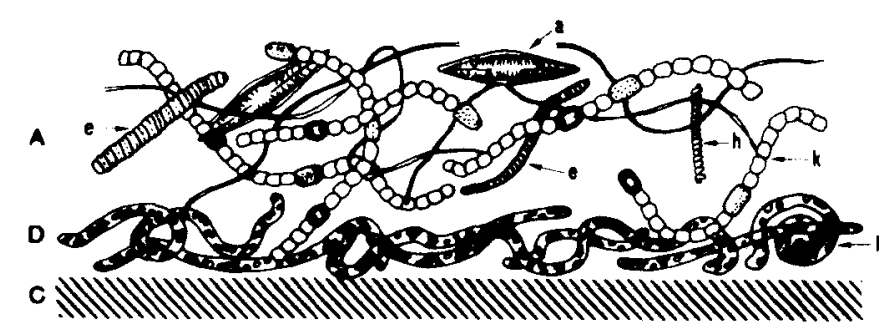

LA ALBARDIOSA

A

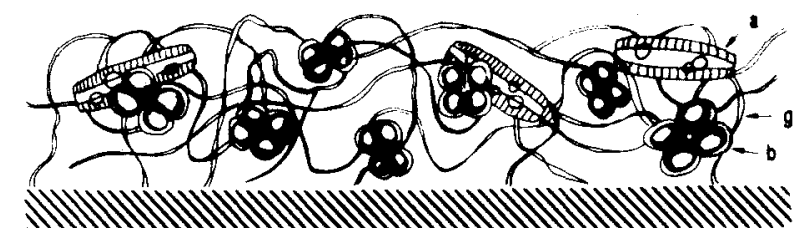

LA DEHESILLA

Figure 3. Drawings of the mann phototrophic and chemotrophic organisms found in microbial mats in four inland saline lakes. a: diatoms; b: Gloeocapsa; c: Synechococcus; d: Microcoleus; e: Oscillatoria; f: Pseudoanabaena; g: LPP; h: Spirulina; i: Chromatium; j: Thiospirillum; k: Anabaena; I: Beggiatoa; m: eukaryotic green algae; A: green layer; B: red layer; D: white layer; C: sediment. (Drawing made by Ana Isabel López)
Among the temporal shallow lakes studied so far, cohesive mats with Microcoleus chthonoplastes as the main matforming organism have been found in "La Muerte" and in "Guallar" in the Aragón endorheic center (Monegros, Zaragoza) and in "Alcahozo" in La Mancha (Ciudad Real). The total area of the submerged sediments in these lakes is colonized by the rnat, and macrophytes are not present. During the summer, these lakes are dry and the benthic communities form typical drought crusts, in which the microorganisms survive in a physiologically inactive form. However, the organisms rapidly become active again upon inundation of the lake.

Microcoleus chthonoplastes is also the dominant matforming cyanobacterium in a the alkaline hyposaline soda lake "Caballo Alba" (Coca, Segovia). This lake has a pH of 10.5-11 and a concentration of dissolved salts of 3-4 g/L. Cohesive mats can be found in dispersed patches on submerged sediments.

A different kind of cohesive mat was found in lake "La Dehesilla" (La Mancha basins, Cuenca). A thin flexible green sheet covers the submerged sediments. The dominant mat-forming organisms in this mat are the large size unicelular cyanobacteria, presumably Gloeocapsa sp., and different very thin filamentous cyanobacteria belonging to the LPP-B group. This mat also forms a drought crust during the dry periods which persists in this lake for approximately nine months. The schematic drawing of the mat is shown in figure 3 , and the yearly cycle, in figure 4 .

Another type of mat was found in the hypersaline lake "Longar" (La Mancha). This lake is hypertrophic due to the input of waste water from the adjacent village Lillo. The surface of exposed wet sediments is covered by a cohesive mat composed of two morphologicaly distinct types of $\mathrm{Osci}$ llatoria with minor contributions of Pseudoanabaena and LPP-forms. Under the green superficial layer (of 1-2 mm thickness), a thin red layer of photosynthetic purple sulphur bacteria developed. The highly eutrophic water column, that has a green colour due to a phytoplanktonic bloom, severely attenuates the irradiance at the sediment surface. As a result, the submerged microbial mats become detached and float on the water. The schematic drawing of microbial population and also the yearly cycle are shown in figures 3 and 4 respectively.

For the remainder of the saline temporal lakes studied so far, microbial mats occur only as very thin green layers. These occur in dispersed patches on exposed sediments which remain in a moisty state due to capillary rise of subsurface water. Characteristically, these mats loose cohe- 


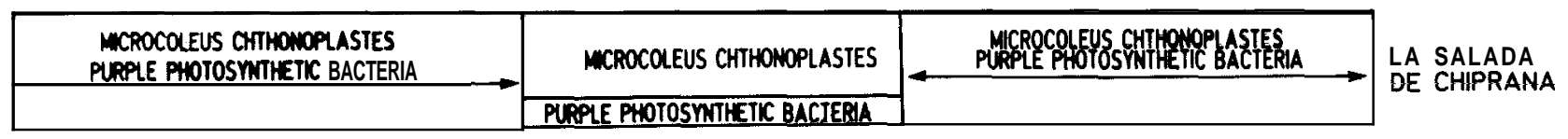
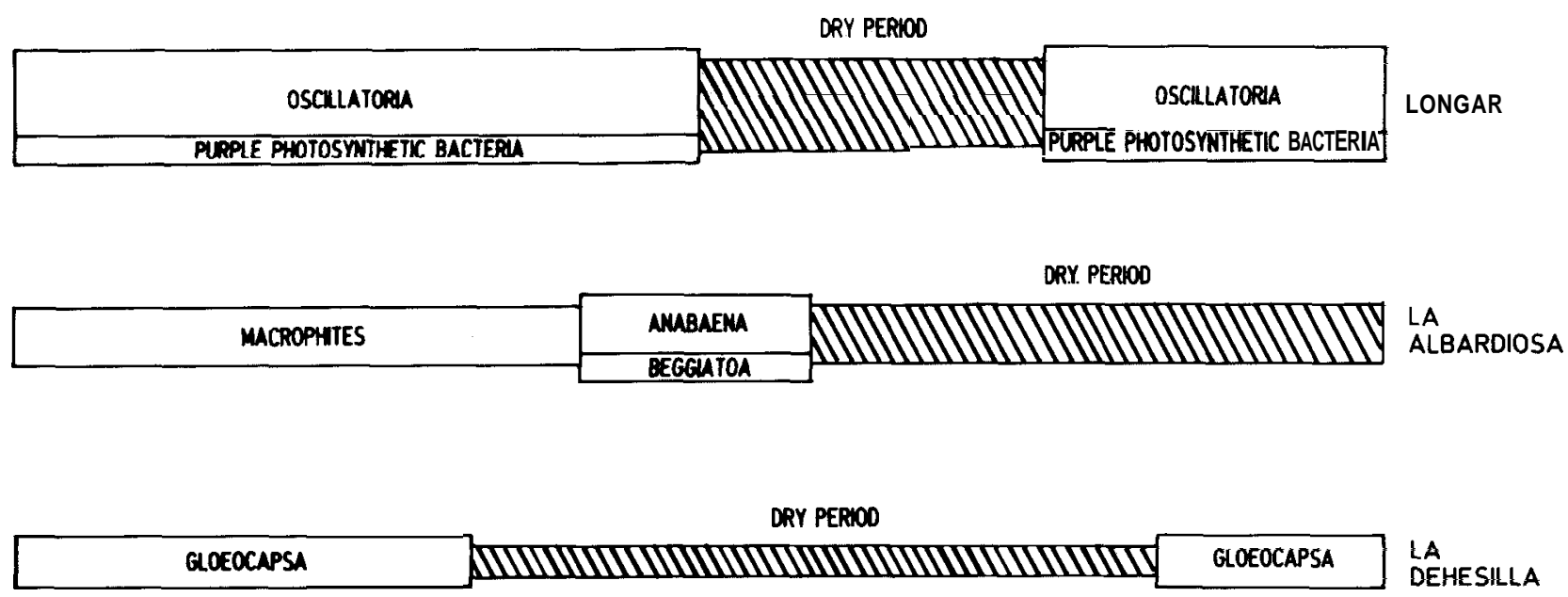

Figure 4. Schematic representation of the seasonal variation of the benthic communities in four inland saline lakes ("La Salada de Chiprana" (Bajo Aragón);"Longar" (La Mancha);"La Albardiosa" (La Mancha);"La Dehesilla" (La Mancha).

siveness and become detached from the sediments upon flooding at the onset of the inundation period. Mat-building organisms in such thin microbial mats include Oscillatoria subbrevis (as e.g. in "Carravalseca", Alava) and Anabaena sp. (as e.g. in "La Albardiosa", La Mancha, Toledo).

A very interesing succession has been found during a year-cycle (1991) in lake "La Albardiosa" (Toledo), which is depicted in figure 4. During this period, the lake changed from subsaline into hypersaline. In early spring, abundant growth occurred of aquatic macrophytes at low salinity and no mats were found. However, the macrophytes died massively upon increasing salinity and, subsequently, thin microbial mats formed by Anabaena colonised the sediments. Below the cyanobacterial layer, a white layer was found which consisted of the chemotrophic sulphur bacterium Beggiatoa. A schematic drawing of mat microbial population is shown in figure 3. The succession started in shalow areas near the shore where hypersaline conditions were established earliest.

As can be apreciated from figure 1, microbial mats have not been found in all Spanish inland saline or alkaline lakes. Obviously, more microbial mats will be discovered in the future when more intensive studies will be performed.
However, presently, it is known that some lakes never contain microbial mats. An intriging case is presented by lake "Piñol" (Aragones center, Monegros, Zaragoza) a hypersaline lake which never contains microbial mats and located only $500 \mathrm{~m}$ apart from lake "La Muerte" with very cohesive mats. Apparently, the climatological and physicochemical properties of both lakes are very similar. Conceivably, the sediment features are another important prerequisite for microbial mat formation. Therefore, we analysed the granulometric composition of both lakes; the results are shown in figure 5 . It turned out that both compositions are only slightly different. However, a clear difference was observed with respect to the fractions of small size (up to $0.1 \mathrm{~mm}$ diameter): these fraction were of negligable importance in "La Muerte", but amounted up to $20 \%$ in "Piñol".

\section{DISCUSSION AND PERSPECTIVES FOR FUTURE RESEARCH}

So far, the study on microbial mats of the inland saline lakes in Spain has been mainly descriptive as it has been in general for the microbial mats in inland saline lakes (BAULD, 1981; BAULD, 1986). Presently, with respect to 
the Iberian Peninsula, we posses a fairly complete knowlegde of the distribution and variability of microbial mats in the inland saline lakes (see fig. 1). Especially, the Aragonés center, the basins in la Mancha, and the lakes in Coca have been visited very intensively. In contrast, Andalucian lakes received less attention so far, and consequently, in the near future, new mats may be discovered in this region. Nevertheless, the data obtained, represent valuable information on the distribution of microbial mats and will serve as a basis to address several questions with respect to microbial mat formation and dynamics.

The ubiquitous benthic cyanobacterium Microcoleus chthonoplastes turned out to be a very succesful organism in inland lakes. This organism formed cohesive mats in the permanent hypersaline Lake Chiprana, in several of the temporal shallow lakes of high salinity, and also in the unique subsaline soda lake "Caballo Alba". As a matter of fact, Microcoleus chthonoplastes was the mat-forming cyanobacterium in most submerged cohesive mats in the inland lakes. Microcoleus chthonoplastes is also common in the coastal environment; it occurs both in supratidal marine mats (ESTEVE et al., 1992) as well as in coastal salinas at salinities from about 80 up to $140 \mathrm{~g} / \mathrm{L}$ (THOMAS, 1984; DE WIT \& GRIMALT, 1992). In addition, in coastal salinas, very consistent mats of Aphanothece spp. and Chromatiaceae are found at salinities ranging from 150 to $300 \mathrm{~g} / \mathrm{L}$. These very high salinities, however, do not occur for prolonged periods in the inland saline lakes.

The tolerance of Microcoleus chthonoplastes to very alkaline conditions in "Caballo Alba", is not a surprise. Microelectrode studies demostrated that highly alkaline conditions often occur during daytime in the cyanobacterial layer of the mats and must be attributed to a very high rate of $\mathrm{CO}_{2}$-fixation (REVSBECH et al., 1983).

Bivalent cations at high concentrations, especially $\mathrm{Mg}^{2+}$, may be toxic and can inhibit growth. It has been reported, that the sensitivity towards these cations is actually increased at higher salinities, and that cyanobacteria are only able to grow at $4 \mathrm{mM} \mathrm{NaCl}$ when bivalent cations are absent (BAAS BECKING. 1931 cited in BAULD, 1981). Nevertheless, abundant Microcoleus mats were found in Lake Chiprana at $70 \mathrm{~g} / \mathrm{L}$ salinity with $\mathrm{Mg}^{2+}$ as the predominant cation. Obviously, the actual $\mathrm{Mg}^{2+}$ tolerance has to be assessed in more detail in growth experiments. It may turn out that this tolerance is actually strain specific, when studying strains from $\mathrm{Mg}^{2+}$ poor and $\mathrm{Mg}^{2+}$ rich environments. Such studies are very relevant for the understanding of evolution in bacterial species. The inland salt lakes constitute an ideal study object since they provide an enormous variation within a geographically relatively small area.

In several lakes, microbial mats only occurred as very thin layers on exposed sediments. These mats with Oscillatoria spp. or Anabaena sp. as the dominant species, became detached from the sediment upon temporal flooding in subsaline water. Apparently, in these mats the ability to maintain cohesiveness in subsaline water is indeed a limiting factor for its occurrence. In contrast, the Microcoleus and Gloeocapsa sp. mats in more saline waters maintained cohesiveness and remained adhered to the sediment throughout the inundation period.

Microbial mats in inland saline lakes are exposed to strong variations of the salinity ( $2.5 \mathrm{t} 5$-fold see fig. 2$)$, such in clear contrast to the mats found in the coastal salinas. Apparently, Microcoleus chthonoplastes is adapted to fluctuating environmental conditions, but it is also competitive under very constant conditions. In the inland lakes, two strategies have been observed which allow the cyanobacteria to cope with the fluctuating conditions. Firstly, cohesive submerged mats of Microcoleus chthonoplastes and Gloeocapsa formed drought crust which survive the dry periods and which rapidly become active again upon wetting. Secondly, the cyanobacteriu'm Anabaena in "La Albardiosa" did not survive the adverse subsaline periods, but demonstrated a very rapid colonisation rate upon the establishment of the favourable conditions.

Mats with heterocystous cyanobacteria as the matforming organisms are very rare, even in inland lakes (BAULD, 1981). STAL \& KRUMBEIN (1985) reported that non-heterocystous filamentous cyanobacteria in microbial mats are actively fixing nitrogen during limited periods of the dial cycle, thus achieving a temporal separation between incompatible oxygen production and nitrogen fixation. So far, it remains to be investigated why in lake "La Albardiosa" the heterocystous Anabaena sp. predominates over such non-heterocystous species.

This study confirmed that at low salinities up to $40 \mathrm{~g} / \mathrm{L}$ the macrophytes mainly Ruppia maritima are more competitive than the microbial mats, but at higher salinities the reverse occurs. Similar observations have been reported for coastal salinas (THOMAS, 1984; DE WIT \& GRIMALT, 1992). In the lake "La Albardiosa" a very interesting cyclical succession was observcd which was directly related to salinity changes. Surprisingly, in lake Chiprana, the microbial mats occurred together with prairies of Ruppia maritima at salinities fluctuating from 30 to $75 \mathrm{~g} / \mathrm{L}$ (see fig. 2). The 

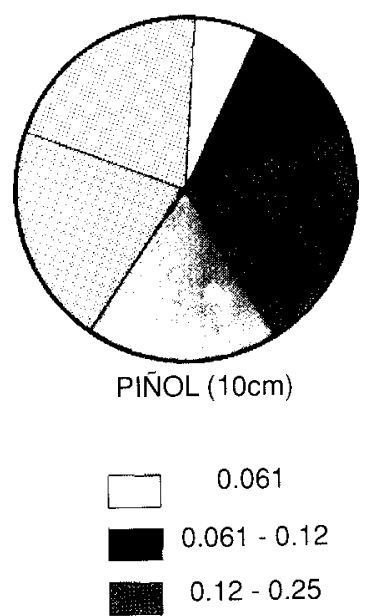

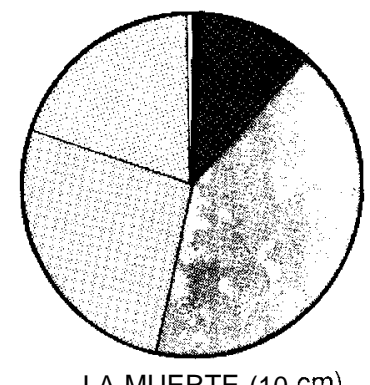

LA MUERTE $(10 \mathrm{~cm})$

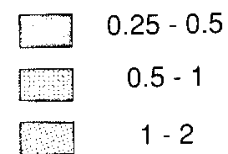

Figure 5. Size distribution of the sediment particles (top $10 \mathrm{~cm}$ ) in two hypersaline temporal lakes in "Loa Monegros" Aragón. Both lakes are separated by $500 \mathrm{~m}$ and have similar climatic and salinity conditions. The sediments of lake "La Muerte" are completely cove red by microbial mats: in contrast, microbial mats are always absent in lake "Piñol".

actual competition between these entities has to be studied in more detail.

As shown above, the study of microbial mats in the diverse inland lakes can significantly contribute to study several ecological, physiological and genetic questions, which are not easily addressed in the coastal environments. Nevertheless, more experimental studies will be required to entangle these questions. The information actually available represents a valuable basis to choose the relevant research objects and sites. It is, however, highly important to maintain the enormous variability found among different inland saline lakes. Therefore, we discuss its actual state of conservation and future perspectives in the following section.

\section{THE URGENT NEED FOR A CONSERVATION POLICY OF THE SPANISH INLAND SALINE LAKES}

The inland saline lakes possess very important naturalistic, scientific, esthetic, economic and cultural values as has been mentioned by various authors (HAMMER, 1986; WILLIAMS, 1986; GONZALEZ BERNALDEZ, 1987). With respect to its scientific values, these lakes are especially important study objects for microbial ecology, because of their interesting microbial ecosystems. Especially, as aforementioned, the study of microbial mats in inland saline lakes may contribute to a better understanding of the general features of these ecosystems. Due to the high population densities and their conspicuous features some of which can even be appreciated with the naked eye, the microbial mats in saline environments represent ideal study sites which can be succesfully studied with current techniques available in microbial ecology. As such, these mats can be studied as model systems, thus allowing to enlarge general knowledge on microbial ecology. Comparably. in the United States, the study of microbial ecosystems in extremely thermal environments greatly expanded general knowledge on general microbiology and microbial ecology (BROCK, 1978).

Unfortunately, the conservation of the inland saline lakes is highly threatened. The general conservation problematics are described by MONTES \& MARTINO (1987), and have been discussed at local scientific meetings (GUERRERO et al.. 1992). The saline lakes have suffered form contamination and eutrophication by discharge of waste water. Presently, large scale extraction of brines causes great damage in some hypersaline lakes. In contrast, traditional small scale salt harvesting in salinas connected with saline lakes can be compatible with the conservation of these lakes and may even give rise to interesting habitats for microbes such as ponds for extremely halophilic archabacteria (DE WIT \& GRIMALT, 1992). The recent large scale extension of agricultural irrigation has a very negative impact on the water regime of the saline lakes. Depending on the local conditions, irrigation can lead either to the increase of the water mass and concurrent desalination due to runoff, or to a drop in the ground water table resulting in increasing salinities and shorter inundation periods.

The interesting microbial mat ecosystems, which have been described in this Chapter, constitute a valuable element of the inland saline lakes. Therefore, we believe it is esssential to conserve these lakes for future generations and counteract the various abovementioned negative developments. Unfortunately, microorganisms and microbial ecosystems often have not been taken into account when establishing priorities for wetland preservation. We believe that the presence of original microbial ecosystems highly justifies a conservation of these wetlands in their natural state.

\section{ACKNOWLEDGEMENTS}

We are indebted to Dr. Carlos Montes for helpfull discussions. Jesús Balsa, M ${ }^{a}$ Luisa Pascual, Ana Belén Tadeo 
contributed during sampling and analyses. This project was partly subsidized by the Spanish Ministry of Education (CAYCIT proy. No. NAT 90-0721-C02-01). Rutger de Wit has been supported by fellowships from the Spanish Ministry of Education and Science and European Environmental Research Organization (E.E.R.O.).

\section{REFERENCES}

COMIN, F. \& M. ALONSO. 1988. Spanish salt lakes. Their chemistry and biota. Hydrobiologia 158:237-245

BAULD, J. 1981. Occurrence of benthic microbial mats in saline lakes. Hydrobiologia 81:87-111

BAULD, J. 1986. Benthic microbial communities of Australian saline lakes. In: P. de Deckker \& W.D. Williams (ed.) Limnology in Australia, pp. 95-111. Dr.W. Junk Pub., Boston. BROCK, Th.D. 1978. Thermophilic microorganisms and life at high temperatures. Springer. New York.

DE WITT, R. \& J. GRIMALT. 1992. Microbial ecosistems in Spanish coastal salinas: an ecological and geochemical study of biomarkers. Limnetica, 8 .

ESTEVE, I.; M. MARTINEZ, J. MIR \& R. GUERRERO. 1992. Distribution, typology and structure of microbial mat communities in Spain: Preliminary studies. Limnetica, 8.

GONZALEZ BERNALDEZ, F. 1987. Las zonas encharcables españolas. El marco conceptual. In: Bases Cientificas para la protección de los humedales en España, pp. 9-30. Real Academia de Ciencias Exactas, Físicas y Naturales de Madrid.
GUERRERO, M.C., J. BALSA, M.L. PASCUAL, B. MARTINEZ, B. \& C. MONTES. 1991. Caracterización limnológica de la laguna Salada de Chiprana (Zaragoza, España) y sus comunidades de bacterias fototróficas. Limnética, 7: 83-96.

GUERRERO, M.C., B. VIDONDO, J. BALSA \& C. MONTES. 1992. La Salada de Chiprana: Características y singularidades. Proceedings of: Jornadas sobre el futuro de las Saladas de Monegros y el Bajo Aragón. Grupo Cultural Caspolino (ed.). Zaragoza (in press).

HAMMER, V.I. 1986. Saline lakes ecosystems of the world. Dr.W. Junk Pub., Boston.

MONTES, C. \& P. MARTINO. 1987. Las lagunas salinas españolas. In: Bases Científicas para la protección de los humedales en España, pp. 95-145. Real Academia de Ciencias Exactas, Físicas y Naturales de Madrid.

REVSBECH, M.P., B.B. JORGENSEN, T.H. BLACKBURN, T.H. \& Y. COHEN. 1983. Microelectrode studies of the photosynthesis and $\mathrm{O}_{2}, \mathrm{H}_{2} \mathrm{~S}$ and $\mathrm{pH}$ profiles in a microbial mat. Limnol. Oceanogr. 28:1062-1074.

STAL, L., H. VAN GEMERDEN \& W.E. KRUMBEIN. 1985. Structure and development of a benthic marine microbial mat. FEMS Microbiol. Ecol. 31:11-125.

THOMAS, J.C. 1984. Formations benthiques: Cyanobactéries des salins de Santa Pola (Espagne): Composition spécifique, morphologie et caractéristiques biologiques des principaux peuplements. Rev. Inv. Geol. 38/39:139-158.

WILLIAMS, W.D. 1986. Limnology, the study of inland waters: a comment on perception of studies of salt lakes, past and present. In: P. de Deckker \& W.D. Williams (ed.) Limnology in Australia, pp. 471-496. Dr.W. Junk Pub., Boston. 